\title{
POSTE RESTANTE
}



Poste Restante A LAWRENCE

\title{
TRAVEL CALENDAR
}

\section{H A R R Y T. M O O R E}

\author{
INTRODUCTION BY
}

MARK SCHORER

UNIVERSITY OF CALIFORNIA PRESS Berkeley and Los Angeles 1956 
University of California Press

Berkeley and Los Angeles, California

\section{Cambridge University Press}

London, England

Copyright, 1956, by

The Regents of the University of California

Excerpts from D. H. Lawrence's letters in this volume are published with the kind permission of The Viking Press, Inc., holders of publication rights in all the Lawrence letters.

Designed by Rita Carroll

Library of Congress Catalog Card No.: 56-8475

Printed in the United States of America 